\title{
肩インピンジメント症候群に対する鏡視下手術の治療経験
}

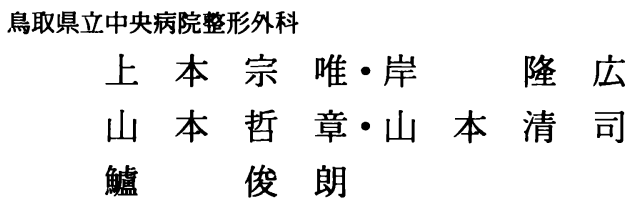

\section{Arthroscopic Surgery for Impingement Syndrome of Shoulder}

\author{
Munetada Kamimoto, Takahiro Kishi, Noriaki Yamamoto, \\ Seishi Yamamoto, and Toshiro Suzuki \\ Department of Orthopaedic Surgery, Tottori Prefectural Central Hospital
}

\begin{abstract}
Arthroscopic subacromial decompression(ASD) was carried out on 12 cases of shoulder impingement syndrome ; 8 males and 4 females ranging in age from 30 to 72 years (average age ; 56 . 6 years). Rotator cuff tears were seen completely in 6 cases, partially in 2 cases, and without 4 cases. The mean time following surgery was 5.3 months, ranging from 3 months to 12 months. At followup all cases were examined by a JOA shoulder score and disapperance of impingement sign. The mean score was 60 points before surgery, improving 86 points during follow - up, which was a significant demonstration of pain relief. Postoperatively 3 cases showed remaining impingement sign. Its causes were dysfuction of the rotator cuff due to complete large tear, shortage of subacromial decompression and remaining calcified deposits. It is essential to evaluate the rotator cuff function before surgery and decide the suitable decompression area during surgery.
\end{abstract}

Key words : shoulder impingement syndrome (肩インピンジメント症候群), arthroscopic surgery (鏡視下手術), arthroscopic subacromial decompression（鏡視下肩峰下徐圧術）

はじめに

肩インピンジメント症候群は, 主に肩峰下関節にお ける障害であり, 近年保存的治療に抵抗する例に対し て鏡視下肩峰下除圧術（以下 ASD と略す）が行われ 良好な治療成績が報告されている2)3). 当院であ 1996 年より ASD を導入し，積極的に治療に取り入れてき た. 今回, その治療成績を調查したので報告する.

\section{対 象}

対象症例は，保存的治療に抵抗するため ASD を施 行した 12 例 12 肩関節である. 男性 8 肩，女性 4 肩， 平均年齢は, 56.6 歳（30７2 歳）であった。発症原
因のはっきりしたものは 3 肩あり, バレーボールのア タックによるあの 1 肩, 転倒による直接打撲 2 肩であっ た。既往歴に糖尿病 2 例, 人工透析 1 例を認めた。 発 症から手術までの期間は平均 1 年 11 ケ月（4 ケ月〜 5 年) であった．腱板断裂は完全断裂 6 肩（大断裂 2 肩, 中断裂 4 肩), 不全断裂 2 肩, 断裂なし 4 肩であっ た. 全例インピンジメントサイン陽性, 肩峰下腔への 局麻剤の注入により一時的な疼痛の消失を認めた。術 後観察期間は平均 5.3 ケ月（ 3 ケ月〜 12 ケ月）であっ た。治療成績は，日整会肩関節治療成績判定基準（以 下 JOA スコアと略す）およびインピンジメントサイ ンの消失の有無により評価した。 


\section{手術手技および後療法}

手術手技は後方アプローチにより肩関節の鏡視をし た後，後外側アプローチにより肩峰下滑液包の鏡視を 行った．前外側より電動シェーバーを用いて肩峰下滑 液包切除を行い，鳥口肩峰勒帯および肩峰下面を確認

表 1 結 果

\begin{tabular}{|c|c|c|c|}
\hline \multicolumn{2}{|c|}{ (1) JOA スコア } & \multicolumn{2}{|l|}{$*: \mathrm{p}<0.05$} \\
\hline & 術 前 & 術 後 & \\
\hline 疼痛 & 7 点 $(5 \sim 10)$ & 23 点（15 30） & * \\
\hline 総合機能 & 7.8 点 $(7 \sim 10)$ & 8.7 点 $(7 \sim 10)$ & \\
\hline 日常生活動作 & 5.7 点 $(4 \sim 10)$ & 8.9 点 $(5 \sim 10)$ & $*$ \\
\hline 可動域 & 20.5 点 $(5 \sim 30)$ & 23.9 点 $(20 \sim 30)$ & \\
\hline 総合評価 & 60 点 (42 77) & 86 点 $(69 \sim 100)$ & * \\
\hline \multicolumn{4}{|c|}{ (2) Impingement sign の有無 } \\
\hline 陽性 & 12 肩 & 3 肩 & \\
\hline
\end{tabular}

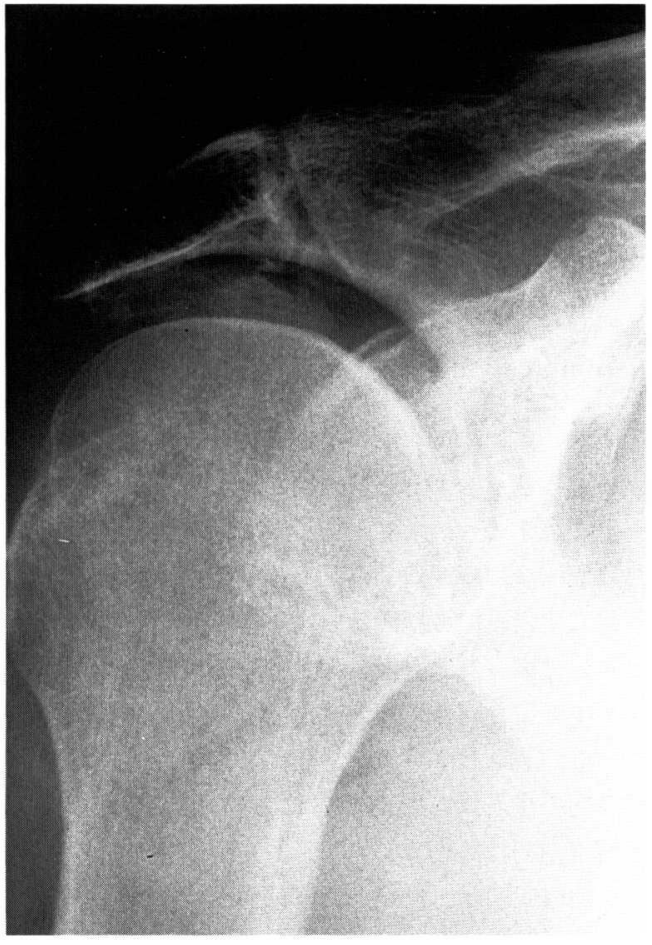

術前
した後，ホルミニウムヤグレーザーを用いて止血を確 認しながら鳥口肩峰勒帯を切離した。最後にアブレッ ダーバーを用いて肩峰下面形成術を行った。 術後は三 角巾による外固定のみで，翌日より他動的可動域訓練 を開始し, 疼痛の軽減をみて介助運動, 自動運動へと 進めた.

\section{結＼cjkstart果（表 1)}

JOA スコアによる総合評価では術前平均 60 点 （42～77 点）から術後平均 86 点（69 100 点）に改善 した。特に疼痛点数の改善が著しく, 術前平均 7 点 （ $5 \sim 10$ 点） 加 術後平均 23 点（15 30 点）に改善 した．完全な除痛が 2 肩，肩をよく使った際の軽度の 疼痛を認めたものが 7 肩と 9 肩に満足すべき除痛が得 られた. さらに除痛とともに日常生活動作も改善され た（術前平均 5.7 点から術後平均 8.9 点）。 また軽度の 除痛は得られたものの不満足でインピンジメントサイ ンの残存したものを 3 肩に認めた。

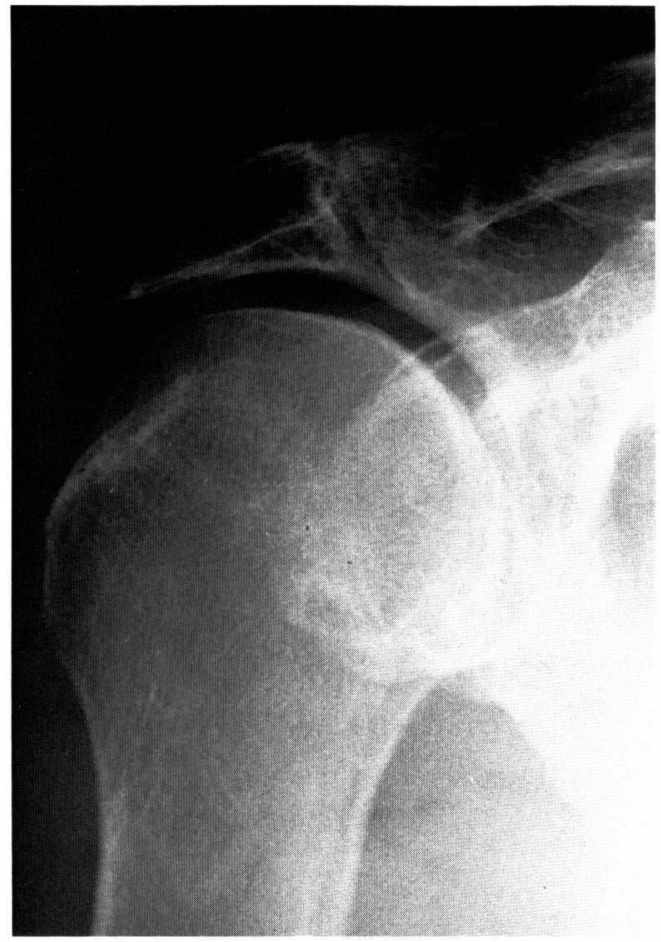

術後 8 个月

図 1 症例 64 歳, 男性. 術前認められた肩峰前外側部の骨棘と烏口峰勒帯の骨化像は, 術後には消失した. 
症

列

64 歳, 男性, 農業, 右利き

主訴 : 右肩関節痛

既往歴 : 特記すべきことなし

現病歴 : 特に誘因なく右肩関節痛出現した.

某整形外科医院で保存的治療を続けていたが，運動痛 に加え，夜間痛が持続するため発症 4 年で ASD を施 行した.

肩関節所見および臨床経過 : 肩関節に不安定性はなく， 自動屈曲 $160^{\circ}$ ，外転 $160^{\circ}$ ，内旋 L 1 ，外旋 $50^{\circ}$ と関 節拘縮は認めない，肩関節造影では肩峰下滑液包への 造影剤の漏出を認め, 腱板完全断裂を合併した Stage IIIインピンジメント症候群と診断した。術後には術前 X線で認められた肩峰前外側部の骨棘および鳥口肩峰 勒帯の骨化は消失した（図 1 ）. 術後 8 ケ月の現在, インピンジメントサインは完全に消失し, JOA スコ アは術前 70 点から術後 98 点に改善した（疼痛点数は 術前 5 点から術後 20 点に改善した).

\section{考 察}

ASD は, 1985 年 Ellman ${ }^{1)}$ によりその良好な治療 成績が報告された．鏡視下手術は，腱板損傷，特に術 前把握しにくい腱板不全断裂や肩峰下滑液包の炎症や 痹着など肩関節構成体の病態を直接鏡視できる, 手術 侵襲・手術疫痕が少ない, 術後の合併症が少ない, 早 期の社会復帰が可能であるなどの利点を有する．本研 究でも術後の感染, 拘縮, 神経麻痺などの合併症は認 めず，満足した除痛の得られた症例では術後の入院期 間は平均 8.5 日であった。
12 例中 9 例（75\%）に満足した除痛が得られたが, 3 例にインピンジメントサインが残存し不満足な除痛 しか得られなかった. その原因は, 除圧不足 1 例, 腱 板断裂による腱板機能低下 1 例, 腱板内石灰沈着の残 存 1 例と考えられた. 腱板断裂例に対する適応, 除圧 範囲の決定が今後の課題になってくるものと思われる. ASD の適応は Stage IIインピンジメント症候群から

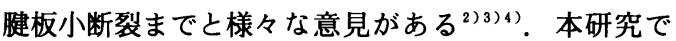
は対象症例は少ないが，中断裂例でも満足した成績が 得られた. したがって腱板完全断裂例であ, 十分挙上 が可能であれば適応になると考えている.

$$
\text { ま と め }
$$

1) 肩インピンジメント症候群に対する ASD の短 期成績を報告した。

2 ) 術前後で JOA スコアの有意な改善が得られ, 特に 12 例中 9 例に満足した除痛が得られた.

3 ）治療成績を向上させるためには, 術前の腱板断 裂による腱板機能の評価及び術中の肩峰下切除範囲の 決定が重要である.

\section{考文 献}

1) Ellman, $\mathrm{H}:$ Arthroscopic subacromial decompression : a preliminary report. Orthop Trans. $9: 49,1985$.

2）黒川正夫 : 肩のインピンジ症候群に対する肩関節鏡視 手術. MB Orthop., 10(13): 37-45, 1997.

3）緑川孝二：高齢者のインピンジメント症候群に対する 鏡視下肩峰下除圧術（ASD）の 術後成績. 関節鏡, 22 : 255-257, 1997.

4）原 正文 : 肩 impingement syndrome に対する鏡視 下手術. MB Orthop., 10(13): 87-96, 1997. 